\title{
Magnetic Susceptibility and Radiological Hazardous Nature of the River Sediments - Spectroscopical Approach
}

\author{
V. Ramasamy ${ }^{a, *}$, G. Suresh ${ }^{a}$, R. Venkatachalapathy ${ }^{b}$, V. Ponnusamy ${ }^{c}$ \\ AND V. MEENAKSHISUNDARAM ${ }^{d}$ \\ ${ }^{a}$ Department of Physics, Annamalai University, Annamalainagar, Tamilnadu, India \\ ${ }^{b}$ CAS in Marine Biology, Annamalai University, Parangipettai, Tamilnadu, India \\ ${ }^{c}$ Department of Physics, Anna University, Chennai, Tamilnadu, India \\ ${ }^{d}$ Health and Safety Division, IGCAR, Kalpakkam, Tamilnadu, India
}

(Received February 24, 2010; in final form June 24, 2010)

\begin{abstract}
Magnetic susceptibility, radioactivity and mineralogical characterization are performed on 40 sediment samples collected from the Ponnaiyar river, Tamilnadu, to establish a possible link between the enhanced concentration of anthropogenic magnetic particles, radionuclides and minerals. Higher magnetic susceptibility values $\left(>150 \times 10^{-8} \mathrm{~m}^{3} / \mathrm{kg}\right)$ are observed in last $100 \mathrm{~km}$ of the river. However, some elevated values are also observed in first $100 \mathrm{~km}$. Frequency dependence of magnetic susceptibility is calculated to understand the magnetic grain variations which are presented and discussed. The average activity concentration of radionuclides $\left({ }^{238} \mathrm{U},{ }^{232} \mathrm{Th}\right.$ and $\left.{ }^{40} \mathrm{~K}\right)$ falls within the typical world and Indian average values although some extreme values are determined. To assess the radiological hazard of river sediments, radiological hazard indices such as absorbed dose rate, annual effective dose equivalent, radium equivalent, hazard indices $\left(H_{\mathrm{ex}}, H_{\mathrm{in}}, I \gamma, I\right.$ and excess lifetime cancer risk) are calculated which shows below the internationally recommended values. The relative distribution of major minerals is determined by calculating extinction coefficient. Correlation analysis is carried out between the parameters obtained from radioactivity analysis and other analyses to know the existing relations. Obtained correlations are discussed and suggest that the natural radioactivity level and magnetic susceptibility of the present sediments is mainly controlled by clay content.
\end{abstract}

PACS numbers: $93.85 . \mathrm{Np}$

\section{Introduction}

The mass-specific magnetic susceptibility $(\chi)$ indicates the amount of magnetic particles in materials like soil, sediments or rocks. Magnetite is of particular importance because of its high $\chi$ value $\left(5-10 \times 10^{-8} \mathrm{~m}^{3} / \mathrm{kg}\right)$ and its widespread occurrence in nature. It can be found in many different kinds of rocks, modern soils and sediments. Magnetic particle can originate from weathered bed rocks, biogenic activity, volcanic ashes or extraterrestrial particles [1]. The spatial and temporal distribution of $\chi$ in the sediments is not only due to variable abundance of iron-bearing ferri- and antiferromagnetic minerals, but also due to the presence of diamagnetic and paramagnetic minerals such as quartz, feldspar, carbonates and clays [2]. Mineral magnetic measurements have been widely used for delineating the environmental pollution during the recent decades, because they are fast, cost-effective, non-destructive and sensitive [3].

River sediments represent a mixture of erosion products of rocks and soils in the catchment area. These sediments have been always important to humans and their health, providing a resource that can be used for different aims. It acts as a natural sink. This means, it

\footnotetext{
* corresponding author; e-mail: srsaranram@rediffmail.com
}

is the record of the input of minerals and other pollutants of different origins from lithogenic/pedogenic and anthropogenic sources. Magnetic susceptibility of these sediments mostly depends on ferromagnetic mineral concentration. These minerals have origin by disintegration of parent rocks during the pedogenesis, by lithogenic process and by anthropogenic activities. In particular, atmospheric deposition on sediments is the principal anthropic cause of magnetic enhancement of sediments. Dust and fly ashes produced by anthropogenic activities (traffic, power plant, metallurgical settlements, and domestic waste) are rich of ferromagnetic particles. Generally, the magnetic properties of the polluted sediments are mainly determined by the anthropogenic portion and to a smaller degree by the natural (lithologic/pedogenic) minerals [3].

Human population is always exposed to ionizing radiation from natural sources. Natural radioactivity is widespread in the earth environment and it exists in various geological formations such as earth crust, rocks, soils, plants, water, air and also trace level in construction materials, which may contribute significantly towards an increased radiation dose received by human beings $[4,5]$. Natural radioactive concentrations mainly depend on geological and geographical condition and appear at different level in soils of different geological region [6]. Soil radionuclide activity concentration is one of the main de- 
terminants of the natural background radiation. When rocks are disintegrated through natural process, radionuclides are carried to soil by rain and flows [7]. In addition to the natural sources, soil radioactivity is also affected by man-made activities. Naturally occurring radionuclides of terrestrial origin are present in river sediments as well [8]. The environmental uranium and partial thorium concentrations are increased due to the fertilizers. Usually fertilizers are considered as technologically enhanced natural radiation [9]. Considerable amounts of natural radio nuclides are found in river sediments as the end result of fertilizer washing and industrial activities [8].

The long-term exposure to uranium and radium through inhalation has several health effects as chronic lung diseases, acute leucopoenia, anemia and necrosis of the mouth. Radium causes bone, cranial, and nasal tumours. Thorium exposure can cause lung, pancreas, hepatic, bone, kidney cancers and leukaemia [7]. Therefore gamma dose rates and radionuclides activity concentrations should be monitored.

Most natural solids are minerals. Sediments are not exemption. These are detrital products of rocks and bear the mineralogical properties of the original rock formation. The principal constituents of most of the sediments are quartz, feldspar, carbonates and clay minerals. Of these, quartz is overwhelmingly the most abundant. Feldspar, though more abundant in parent igneous rock, is of intermediate durability and so runs second place to quartz in sediments. The others, though more durable than feldspar, are simply far less abundant in source materials [10]. The mineralogical properties of sediments reflect the geological history of transport and sorting process. The Fourier transform infrared (FTIR) absorption spectra of sediments contain more information about mineralogy [11]. It is used by mineralogists and sedimentary petrologists in the aspect of mineralogical application.

Based on the above discussion, the river sediments are enriched by magnetic pollutants, terrestrial radionuclides and minerals. Magnetic susceptibility of sediments was studied by many authors [12-15]. Especially, Chaparro et al., $[12,13]$ proved that magnetic susceptibility is able to reflect anthropogenic input into river sediments. Radioactivity of river sediments was measured by many authors $[8,9,16-18]$. The infrared spectra of river sediments from Cauvery and Vellar have been characterized by Ramasamy et al., [19, 20].

Hence, the objective of this study is to (i) analyse the magnetic susceptibility, natural radiation level and mineral characteristics of the sediments of Ponnaiyar River, Tamilnadu, India, (ii) calculate the radiological parameters and extinction coefficient in order to know the complete radiological characteristics and relative distribution of major minerals, respectively, (iii) correlate the parameters obtained from radioactivity analysis with parameters obtained from other analyses to know the existing relations.

\section{Materials and methods \\ 2.1. Study area}

In the present study, sediment samples were collected from various sites of the Ponnaiyar river. It is originated from the hills of Nandidrug in Kolar district of Karnataka state, and flows south and then east for $400 \mathrm{~km}$ through Karnataka and Tamilnadu and terminated at Cuddalore, Tamilnadu in Bay of Bengal. It is entered in Tamilnadu at Dharmapuri district. It covers four districts (Dharmapuri, Thiruvannamalai, Villupuram and Cuddalore) in Tamilnadu. A dam is situated on the river at Satthanur, Chengam taluk, Thiruvannamalai district with a capacity of nearly $1288 \mathrm{Mm}^{3}$. The small hydraulic structure and barrages were constructed for drinking and agriculture purposes respectively on the study area. On both side of the bank of this river, so many living residents and some industries are situated. None of the industrials have proper and controlled outlet. The discharge wastes and toxic metals from such industries and living residents are directly let out into the river. Also along the river, lot of agricultural lands is available, overuse of chemical fertilizers and pesticides are washed into the river. These are all main factors for enrichment of pollutants in the study area. The sediments of this river are excavated only for building construction purposes.

\subsection{Sample collection and preparation}

The present study area (Ponnaiyar river) (Fig. 1) covers a total length of $200 \mathrm{~km}$ from which 40 locations were selected. Location of sampling site with their latitude and longitude are given in Table I. Each location is separated by a distance of $4-5 \mathrm{~km}$ approximately. All sediment samples were collected at $0-10 \mathrm{~cm}$ depth during the summer season (April-May 2008). Each sample has a weight of 3-4 kg approximately. The collected samples were dried at room temperature in open air for two days and stored in black polythene bags.



Fig. 1. Location of Ponnaiyar river with their experimental sites in Tamilnadu.

\subsubsection{Magnetic susceptibility measurements}

The dry sediment samples were sealed with cling film then packed with paleomagnetic plastic boxes $\left(8 \mathrm{~cm}^{3}\right)$ and the net weight was determined before magnetic 
measurements. Such specimens were hardened using a sodium silicate solution. Magnetic susceptibility measurements were carried out using a magnetic susceptibility meter, Bartington Instruments Ltd., linked to MS2B dual frequency sensor $(0.47$ and $4.7 \mathrm{kHz})$. For the laboratory measurements, five readings were taken for each sample in two different frequencies (low and high) and an average is calculated. The accuracy is about $1 \%$.

\subsubsection{Radioactivity measurements}

The samples were dried in an oven $110^{\circ} \mathrm{C}$ till the constant dry weight was obtained, crushed and homogenized. The homogenized samples were packed in a $250 \mathrm{ml}$ plastic container $(9 \mathrm{~cm} \times 6.5 \mathrm{~cm}$ : height $\times$ diameter $)$ to its full volume with uniform mass. These containers were shielded hermetically and also shielded externally to ensure that all daughter products of uranium and thorium, in particular, radon isotope formed, do not escape. A time of four weeks was allowed after packing to attain secular equilibrium between Ra-226 and its short-lived daughter products. The net weight of the sample was determined before counting.

The gamma ray spectrometer with $\mathrm{NaI}(\mathrm{Tl})$ detector was used to determine the concentration of primordial radionuclides $\left({ }^{238} \mathrm{U},{ }^{232} \mathrm{Th}\right.$ and $\left.{ }^{40} \mathrm{~K}\right)$. The detector was shielded by $15 \mathrm{~cm}$ thick lead on all four sides and $10 \mathrm{~cm}$ thick on top. The energy resolution of $2.0 \mathrm{keV}$ and relative efficiency of $33 \%$ at $1.33 \mathrm{MeV}$ was achieved in the system with the counting time of $10000 \mathrm{~s}$. The standard International Atomic Energy Agency (IAEA) sources were used for calibration. From the counting spectra, the activity concentrations of ${ }^{238} \mathrm{U},{ }^{232} \mathrm{Th}$ and ${ }^{40} \mathrm{~K}$ were determined using computer program. The peak corresponds to $1460 \mathrm{keV}$ (K-40) for ${ }^{40} \mathrm{~K}, 1764.5 \mathrm{keV}$ (Bi-214) for ${ }^{238} \mathrm{U}$ and $2614.5 \mathrm{keV}$ (Ti-208) for ${ }^{232} \mathrm{Th}$ were considered in arriving at the activity levels $(\mathrm{Bq} / \mathrm{kg})$.

\subsubsection{Mineralogical study}

Wet grinding was carried out by placing 30 to $50 \mathrm{mg}$ of the sample in an agate mortar along with 20 to 25 drops of ethanol. The ground samples were dried in a hot air oven at $110^{\circ} \mathrm{C}$ to remove the moisture content and sieved to $53 \mu \mathrm{m}$ grain size. Using the $\mathrm{KBr}$ pellet technique, sample was mixed with $\mathrm{KBr}$ at various ratios viz., 1:10, 1:20, 1:30, 1:40 and 1:50. The mixture was then pressed into a transparent disc in an evacuable dye at sufficiently high pressure. The samples in the ratio 1:30 was taken for further analysis, since it gives rise to maximum transmittance and observable peaks. Using the Perkin Elmer RX1 FTIR spectrometer, the infrared spectra for all sediment samples were recorded in the region $4000-400 \mathrm{~cm}^{-1}$. The resolution of the instruments is $0.001 \mathrm{~cm}^{-1}$ and the accuracy is $\pm 4 \mathrm{~cm}^{-1}$.

\section{Results and discussion}

The magnetic susceptibility values of the sediment samples are given in Table I. Magnetic susceptibility ranges from $11.00 \times 10^{-8} \mathrm{~m}^{3} / \mathrm{kg}\left(\mathrm{S}_{5}\right)$ to $260.10 \times$ $10^{-8} \mathrm{~m}^{3} / \mathrm{kg}\left(\mathrm{S}_{39}\right)$. Within the upper most $100 \mathrm{~km}$ from the origin show lower susceptibility values than next $100 \mathrm{~km}$ of the river. More downstream of the river has quite higher magnetic susceptibility values. Yang et al. [3] suggested that magnetic susceptibility of the sediment was controlled by anthropogenic sources like particles from vehicles, emission from industrial and fossil fuel combustion, fertilizers, pesticides, etc., Site numbers $\mathrm{S}_{12}, \mathrm{~S}_{19}, \mathrm{~S}_{21}$ and $\mathrm{S}_{35}$ have considerably higher susceptibility values which may be due to the traffic effluents, since the national highways and bridges are situated at above four sites. In these sites, the geological background as well as anthropogenic particles is considered as a significant source of magnetic susceptibility. In comparison with ranges of magnetic susceptibility found in urban top soils, China [21] and lake sediments, China [3], the ranges of present study $\left(11.00 \times 10^{-8}\right.$ to $\left.260.10 \times 10^{-8} \mathrm{~m}^{3} / \mathrm{kg}\right)$ is lower.

In between the site number $S_{11}$ and $S_{12}$, the Thirukovilur town exists, solid wastes from living residence are disposed into the river at these sites, which may lead to the enhanced magnetic susceptibility values [1]. According to Yang et al. [3], if the magnetic susceptibility values from the pollution sources are greater than $150 \times 10^{-8} \mathrm{~m}^{3} / \mathrm{kg}$, those values may be treated as higher magnetic susceptibility values. In the present study, higher susceptibility $\left(>150 \times 10^{-8} \mathrm{~m}^{3} / \mathrm{kg}\right)$ is observed in site numbers $\mathrm{S}_{36}-\mathrm{S}_{40}$, which may be due to the abundance of clay minerals along with some pollution sources (atmospheric deposition from Cuddalore town).

Since magnetic susceptibility is dependent on concentration as well as grain size, low concentration of superparamagnetic (SP) grains as well as high concentration of single domain (SD) grains can result in similar susceptibility signals. To determine whether the high susceptibility signal results from either concentration or grain size, susceptibility ratio known as frequency dependence of susceptibility can be used. Also it is used to determine the contribution of SP material to the signal. The percentage of frequency dependence $(\% \mathrm{fd})$ is calculated (Table I) using the formula

$$
\chi_{\mathrm{fd}} \%=\frac{\left(\chi_{\mathrm{lf}}-\chi_{\mathrm{hf}}\right)}{\chi_{\mathrm{lf}}} \times 100
$$

where $\chi_{\mathrm{lf}}$ and $\chi_{\mathrm{hf}}$ is the low and high frequency susceptibility $\left(\times 10^{-8} \mathrm{~m}^{3} / \mathrm{kg}\right)$, respectively. In this study, $\chi_{\mathrm{fd}} \%$ varies from 0.12 to $8.56 \%$. The frequency dependence of magnetic susceptibility $\left(\chi_{\mathrm{fd}} \%\right)$ is a diagnostic parameter to understand the magnetic grain variation. For the SP /SD grain size, $\chi_{\mathrm{fd}} \%$ lies in the range of $7-15 \%$, while for multidomain (MD) grains $\chi_{\mathrm{fd}}$ is $<5-6 \%$ [18]. Site number $\mathrm{S}_{12}, \mathrm{~S}_{19}, \mathrm{~S}_{21}, \mathrm{~S}_{35}, \mathrm{~S}_{37}$ and $\mathrm{S}_{38}$ have elevated $\chi_{\mathrm{fd}} \%$ values $(>7 \%)$. According to Maher [22] this elevation may be due to the superparamagnetic/single domain grains from traffic exhaust. The $\chi_{\mathrm{fd}} \%$ of the other sites are within the value of $<5-6 \%$. This suggests that multidomain grains may contribute to total magnetic susceptibility. 


\section{Radioactivity nature of the sediment}

The activity concentrations of the radionuclides ${ }^{238} \mathrm{U}$, ${ }^{232} \mathrm{Th}$ and ${ }^{40} \mathrm{~K}$ in the Ponnaiyar river sediment samples (Table I) are measured. The activity concentration ranges for ${ }^{238} \mathrm{U},{ }^{232} \mathrm{Th}$ and ${ }^{40} \mathrm{~K}$ are BDL $-11.60 \pm$ $6.13 \mathrm{~Bq} / \mathrm{kg}$ with an average $7.31 \pm 3.41 \mathrm{~Bq} / \mathrm{kg}, \mathrm{BDL}-$ $106.11 \pm 9.20 \mathrm{~Bq} / \mathrm{kg}$ with an average $46.85 \pm 5.25 \mathrm{~Bq} / \mathrm{kg}$ and $201.23 \pm 19.90-467.71 \pm 34.34 \mathrm{~Bq} / \mathrm{kg}$ with an average $384.03 \pm 26.82 \mathrm{~Bq} / \mathrm{kg}$, respectively. The activity concentrations vary from site to site, because river bottoms can exhibit large variations in chemical, mineralogical properties and rare earth elements [8, 23].

The highest concentration of ${ }^{238} \mathrm{U}$ is found in site number $\mathrm{S}_{2}$, whereas their lowest concentration is found in $\mathrm{S}_{33}$, $\mathrm{S}_{36}$ and $\mathrm{S}_{38}$. The enhanced ${ }^{238} \mathrm{U}$ concentration in $\mathrm{S}_{2}$ may be due to the solubility and mobility of $\mathrm{U}(\mathrm{VI}) \mathrm{O}_{2}^{2+}[16]$. The highest concentration of ${ }^{232} \mathrm{Th}$ and ${ }^{40} \mathrm{~K}$ are observed in site number $\mathrm{S}_{40}$, whereas their lowest concentrations are found in site number $\mathrm{S}_{3}$ and $\mathrm{S}_{1}$, respectively. El-Gamal et al. [9] have reported of the activity concentration of radionuclides for the Nile river sediments. They stated that high concentration of ${ }^{232} \mathrm{Th}$ and ${ }^{40} \mathrm{~K}$ of river sediment are related to clay content, while the lower concentration of radionuclides are related to sandy content. The elevated concentration of those radionuclides in $\mathrm{S}_{40}$ may be due to the abundance of clay sediments. The lowest concentration of such radionuclides may be due to the sandy nature of sediments.

The mean activity concentration of ${ }^{238} \mathrm{U}$ is 0.22 times the world average value $(33 \mathrm{~Bq} / \mathrm{kg})$ and 0.25 times the Indian average value $(28.67 \mathrm{~Bq} / \mathrm{kg})$ [6], whereas the mean concentration of ${ }^{232} \mathrm{Th}$ is 1.04 and 0.74 times the world average $(45 \mathrm{~Bq} / \mathrm{kg})$ and Indian average value (63.83 Bq/kg) [6], respectively. The mean concentration of ${ }^{40} \mathrm{~K}$ is 0.91 times the world average value $(420 \mathrm{~Bq} / \mathrm{kg})$ and 0.96 times Indian average value $(400 \mathrm{~Bq} / \mathrm{kg})[6]$, respectively. The measured concentrations of ${ }^{238} \mathrm{U}$ and ${ }^{232} \mathrm{Th}$ (present study) are lower than the values obtained for the Danube river [24], Nile river [9] and Reedy river [16] sediments. However, the concentration of ${ }^{232} \mathrm{Th}$ in the present study is similar to the values registered by Descamps and Foulquier [25] and Powell et al. [16] for French and Reedy river, respectively. El-Gamal et al. [9] and Chowdhury et al. [26] have obtained the lower concentration of ${ }^{40} \mathrm{~K}$ in river sediments when compared with present study (Table I). Especially, in Tamilnadu, Ramasamy et al. $[17,18]$ reported the activity concentration of Palar and Cauvery river, which are higher than the present values.

\subsection{Absorbed dose rate (D)}

Radiation exposure are measured in terms of the quantity "absorbed dose rate", which is equal to the energy deposited per unit mass in the irradiated medium. It is the major step for evaluating the health risk and is expressed in gray (Gy). Nature of biological effect, radiological and clinical effects is directly related to the absorbed dose rate.
The measured activity concentration of ${ }^{238} \mathrm{U},{ }^{232} \mathrm{Th}$ and ${ }^{40} \mathrm{~K}$ are converted into doses by applying the conversion factors $0.462,0.604$, and 0.0417 for uranium, thorium, and potassium, respectively $[5,6]$. These factors are used to calculate the total dose rate $(D)(\mathrm{nGy} / \mathrm{h})$ using the following equation:

$$
D=\left(0.462 C_{\mathrm{U}}+0.604 C_{\mathrm{Th}}+0.0417 C_{\mathrm{K}}\right),
$$

where $C_{\mathrm{U}}, C_{\mathrm{Th}}$, and $C_{\mathrm{K}}$ are the activity concentrations $(\mathrm{Bq} / \mathrm{kg})$ of ${ }^{238} \mathrm{U},{ }^{232} \mathrm{Th}$, and ${ }^{40} \mathrm{~K}$ in river sediments, respectively. The range of absorbed dose rates (Table II) is from 16.48 to $86.17 \mathrm{nGy} / \mathrm{h}$ with an average of $47.07 \mathrm{nGy} / \mathrm{h}$. Average absorbed dose rate for all samples is lower than the world average value $(57 \mathrm{nGy} / \mathrm{h})[6]$. The absorbed dose rates are changed according to the spatial variations of minerals (discussed elsewhere) holding sediments [9].

\subsection{The annual effective dose equivalent (AEDE)}

Since the Ponnaiyar river sediments are the main mixing material with cement and cement products for building construction in Tamilnadu, the determination of AEDE of each site sample assume importance. For that, the living style of the people or indoor or outdoor factor of a location is considered.

A typical resident in a location, both male and female, would spent about $8 \mathrm{~h}$ of the day in an office or class room or laboratory, $11 \mathrm{~h}$ indoors and the remaining $5 \mathrm{~h}$ outdoors. This applies to the greater part of the population in a location who are either office worker or public/ students. Hence, 19/24 (0.8) and 5/24 (0.2) is adopted as the indoor (80\%) and outdoor occupancy factor $(20 \%)$, respectively, with conversion factor of $0.7 \mathrm{~Sv} / \mathrm{Gy}$ to convert absorbed dose rate $(\mathrm{nGy} / \mathrm{h})$ to annual effective dose equivalent $(\mu \mathrm{Sv} / \mathrm{y})$ for this study [27].

The annual effective dose is determined using the following equations:

$$
\begin{aligned}
& \text { AEDE (outdoor) }[\mu \mathrm{Sv} / \mathrm{y}] \\
& \quad=(\text { absorbed dose })[\mathrm{nGy} / \mathrm{h} \times 8760 \mathrm{~h} \\
& \left.\quad \times 0.7 \mathrm{~Sv} / \mathrm{Gy} \times 0.2 \times 10^{-3}\right], \\
& \text { AEDE }(\text { indoor })[\mu \mathrm{Sv} / \mathrm{y}] \\
& \quad=(\text { absorbed dose })[\mathrm{nGy} / \mathrm{h} \times 8760 \mathrm{~h} \\
& \left.\quad \times 0.7 \mathrm{~Sv} / \mathrm{Gy} \times 0.8 \times 10^{-3}\right] .
\end{aligned}
$$

From the calculated values of AEDE (Table II), the average, minimum and maximum value for outdoor and indoor is found to be $57.73 \mu \mathrm{Sv} / \mathrm{y}, 20.21 \mu \mathrm{Sv} / \mathrm{y}$ and $105.68 \mu \mathrm{Sv} / \mathrm{y}$, respectively and $230.92 \mu \mathrm{Sv} / \mathrm{y}$, $80.82 \mu \mathrm{Sv} / \mathrm{y}$, and $422.73 \mu \mathrm{Sv} / \mathrm{y}$, respectively. The average values of both indoor and outdoor AEDE is lower than the world average values $(70 \mu \mathrm{Sv} / \mathrm{y}$ for outdoor, $450 \mu \mathrm{Sv} / \mathrm{y}$ for indoor) [28]. There are some limited locations $\left(\mathrm{S}_{28}\right.$ to $\left.\mathrm{S}_{40}\right)$ where the outdoor AEDE do exceed the world average due to the presence of high activity concentration of ${ }^{232} \mathrm{Th}$ and ${ }^{40} \mathrm{~K}$. However, most of the locations satisfy the criteria for the radiation safety point of view. 
TABLE I

Location of the sampling sites and their magnetic susceptibility (LF and HF), \% of frequency dependence (FD \%) and activity concentrations of radionuclides.

\begin{tabular}{|c|c|c|c|c|c|c|c|c|}
\hline \multirow[t]{2}{*}{ Site number } & \multirow[t]{2}{*}{ Latitude } & \multirow[t]{2}{*}{ Longitude } & \multicolumn{2}{|c|}{$\begin{array}{l}\text { Magnetic susceptibility } \\
{\left[\times 10^{-8} \mathrm{~m}^{3} / \mathrm{kg}\right]}\end{array}$} & \multirow[t]{2}{*}{ FD \% } & \multicolumn{3}{|c|}{$\begin{array}{c}\text { Activity concentration } \\
{[\mathrm{Bq} / \mathrm{kg}]}\end{array}$} \\
\hline & & & $\mathrm{LF}$ & $\mathrm{HF}$ & & ${ }^{238} \mathrm{U}$ & ${ }^{232} \mathrm{Th}$ & ${ }^{40} \mathrm{~K}$ \\
\hline $\mathrm{S}_{1}$ & $12^{\circ} 10^{\prime} 606^{\prime \prime} \mathrm{N}$ & $78^{\circ} 50^{\prime} 464^{\prime \prime} \mathrm{E}$ & 68.0 & 67.8 & 0.29 & $9.51 \pm 4.21$ & $6.11 \pm 4.69$ & $201.23 \pm 23.96$ \\
\hline $\mathrm{S}_{2}$ & $12^{\circ} 07^{\prime} 978^{\prime \prime} \mathrm{N}$ & $78^{\circ} 53^{\prime} 950^{\prime \prime} \mathrm{E}$ & 62.0 & 61.7 & 0.48 & $11.6 \pm 6.13$ & $6.91 \pm 9.20$ & $287.81 \pm 25.36$ \\
\hline $\mathrm{S}_{3}$ & $12^{\circ} 06^{\prime} 415^{\prime \prime} \mathrm{N}$ & $78^{\circ} 55^{\prime} 087^{\prime \prime} \mathrm{E}$ & 13.3 & 13 & 2.26 & $7.89 \pm 3.96$ & BDL & $279.10 \pm 26.17$ \\
\hline $\mathrm{S}_{4}$ & $12^{\circ} 06^{\prime} 414^{\prime \prime} \mathrm{N}$ & $78^{\circ} 55^{\prime} 075^{\prime \prime} \mathrm{E}$ & 14.4 & 14.2 & 1.39 & $8.11 \pm 4.11$ & $7.21 \pm 4.19$ & $282.64 \pm 25.11$ \\
\hline $\mathrm{S}_{5}$ & $12^{\circ} 06^{\prime} 416^{\prime \prime} \mathrm{N}$ & $78^{\circ} 55^{\prime} 080^{\prime \prime} \mathrm{E}$ & 11.0 & 10.9 & 0.91 & $7.97 \pm 3.65$ & $8.76 \pm 4.33$ & $305.01 \pm 27.28$ \\
\hline $\mathrm{S}_{6}$ & $12^{\circ} 00^{\prime} 677^{\prime \prime} \mathrm{N}$ & $79^{\circ} 03^{\prime} 273^{\prime \prime} \mathrm{E}$ & 20.8 & 20.6 & 0.96 & $7.32 \pm 3.54$ & $8.18 \pm 3.95$ & $329.52 \pm 25.32$ \\
\hline $\mathrm{S}_{7}$ & $12^{\circ} 00^{\prime} 104^{\prime \prime} \mathrm{N}$ & $79^{\circ} 04^{\prime} 169^{\prime \prime} \mathrm{E}$ & 18.2 & 18.1 & 0.55 & $8.13 \pm 4.21$ & $9.55 \pm 4.33$ & $306.83 \pm 34.34$ \\
\hline $\mathrm{S}_{8}$ & $12^{\circ} 00^{\prime} 271^{\prime \prime} \mathrm{N}$ & $79^{\circ} 05^{\prime} 481^{\prime \prime} \mathrm{E}$ & 97.0 & 96.2 & 0.82 & $7.23 \pm 3.95$ & $8.98 \pm 4.26$ & $342.63 \pm 26.17$ \\
\hline $\mathrm{S}_{9}$ & $11^{\circ} 58^{\prime} 786^{\prime \prime} \mathrm{N}$ & $79^{\circ} 06^{\prime} 923^{\prime \prime} \mathrm{E}$ & 33.0 & 31.5 & 4.55 & $7.11 \pm 3.65$ & $11.88 \pm 3.62$ & $384.97 \pm 26.42$ \\
\hline $\mathrm{S}_{10}$ & $11^{\circ} 58^{\prime} 007^{\prime \prime} \mathrm{N}$ & $79^{\circ} 07^{\prime} 880^{\prime \prime} \mathrm{E}$ & 33.2 & 33.1 & 0.30 & $7.54 \pm 3.45$ & $10.99 \pm 4.01$ & $378.79 \pm 25.96$ \\
\hline $\mathrm{S}_{11}$ & $11^{\circ} 57^{\prime} 860^{\prime \prime} \mathrm{N}$ & $79^{\circ} 09^{\prime} 838^{\prime \prime} \mathrm{E}$ & 129.0 & 127.5 & 1.16 & $7.88 \pm 3.65$ & $12.35 \pm 4.26$ & $385.55 \pm 26.44$ \\
\hline $\mathrm{S}_{12}$ & $11^{\circ} 58^{\prime} 400^{\prime \prime} \mathrm{N}$ & $79^{\circ} 12^{\prime} 726^{\prime \prime} \mathrm{E}$ & 139.0 & 127.1 & 8.56 & $8.01 \pm 4.51$ & $19.32 \pm 4.44$ & $363.05 \pm 19.90$ \\
\hline $\mathrm{S}_{13}$ & $11^{\circ} 56^{\prime} 876^{\prime \prime} \mathrm{N}$ & $79^{\circ} 14^{\prime} 198^{\prime \prime} \mathrm{E}$ & 30.1 & 29.8 & 1.00 & $7.32 \pm 3.11$ & $15.39 \pm 4.37$ & $388.55 \pm 26.44$ \\
\hline $\mathrm{S}_{14}$ & $11^{\circ} 56^{\prime} 734^{\prime \prime} \mathrm{N}$ & $79^{\circ} 18^{\prime} 353^{\prime \prime} \mathrm{E}$ & 25.6 & 25.4 & 0.78 & $7.13 \pm 2.98$ & $20.94 \pm 4.51$ & $381.11 \pm 26.98$ \\
\hline $\mathrm{S}_{15}$ & $11^{\circ} 54^{\prime} 832^{\prime \prime} \mathrm{N}$ & $79^{\circ} 18^{\prime} 771^{\prime \prime} \mathrm{E}$ & 19.5 & 19.4 & 0.51 & $7.56 \pm 3.41$ & $24.26 \pm 4.60$ & $354.77 \pm 26.14$ \\
\hline $\mathrm{S}_{16}$ & $11^{\circ} 54^{\prime} 402^{\prime \prime} \mathrm{N}$ & $79^{\circ} 20^{\prime} 273^{\prime \prime} \mathrm{E}$ & 20.4 & 19.9 & 2.45 & $7.54 \pm 3.65$ & $26.25 \pm 4.57$ & $382.33 \pm 29.11$ \\
\hline $\mathrm{S}_{17}$ & $11^{\circ} 55^{\prime} 082^{\prime \prime} \mathrm{N}$ & $79^{\circ} 22^{\prime} 377^{\prime \prime} \mathrm{E}$ & 40.1 & 40 & 0.25 & $6.98 \pm 3.98$ & $25.68 \pm 4.59$ & $380.21 \pm 25.69$ \\
\hline $\mathrm{S}_{18}$ & $11^{\circ} 54^{\prime} 172^{\prime \prime} \mathrm{N}$ & $79^{\circ} 24^{\prime} 086^{\prime \prime} \mathrm{E}$ & 39.7 & 39.6 & 0.25 & $7.12 \pm 3.48$ & $29.71 \pm 4.75$ & $388.97 \pm 27.41$ \\
\hline $\mathrm{S}_{19}$ & $11^{\circ} 52^{\prime} 354^{\prime \prime} \mathrm{N}$ & $79^{\circ} 26^{\prime} 245^{\prime \prime} \mathrm{E}$ & 110.3 & 102.5 & 7.07 & $7.56 \pm 3.85$ & $33.95 \pm 4.76$ & $388.08 \pm 27.39$ \\
\hline $\mathrm{S}_{20}$ & $11^{\circ} 52^{\prime} 065^{\prime \prime} \mathrm{N}$ & $79^{\circ} 28^{\prime} 584^{\prime \prime} \mathrm{E}$ & 28.5 & 28.1 & 1.40 & $6.99 \pm 3.01$ & $37.90 \pm 5.07$ & $397.01 \pm 27.78$ \\
\hline $\mathrm{S}_{21}$ & $11^{\circ} 51^{\prime} 688^{\prime \prime} \mathrm{N}$ & $79^{\circ} 29^{\prime} 731^{\prime \prime} \mathrm{E}$ & 143.0 & 132.1 & 7.62 & $7.21 \pm 3.21$ & $38.2 \pm 5.15$ & $385.55 \pm 26.44$ \\
\hline $\mathrm{S}_{22}$ & $11^{\circ} 51^{\prime} 309^{\prime \prime} \mathrm{N}$ & $79^{\circ} 30^{\prime} 778^{\prime \prime} \mathrm{E}$ & 35.6 & 35.2 & 1.12 & $7.24 \pm 3.26$ & $42.36 \pm 5.56$ & $399.32 \pm 29.12$ \\
\hline $\mathrm{S}_{23}$ & $11^{\circ} 50^{\prime} 533^{\prime \prime} \mathrm{N}$ & $79^{\circ} 33^{\prime} 457^{\prime \prime} \mathrm{E}$ & 35.7 & 35.6 & 0.28 & $6.96 \pm 3.01$ & $48.69 \pm 5.87$ & $402.68 \pm 27.01$ \\
\hline $\mathrm{S}_{24}$ & $11^{\circ} 50^{\prime} 367^{\prime \prime} \mathrm{N}$ & $79^{\circ} 33^{\prime} 916^{\prime \prime} \mathrm{E}$ & 16.4 & 16.2 & 1.22 & $6.71 \pm 2.98$ & $58.48 \pm 3.80$ & $406.82 \pm 30.53$ \\
\hline $\mathrm{S}_{25}$ & $11^{\circ} 50^{\prime} 406^{\prime \prime} \mathrm{N}$ & $79^{\circ} 35^{\prime} 451^{\prime \prime} \mathrm{E}$ & 84.2 & 84.1 & 0.12 & $6.64 \pm 2.69$ & $66.25 \pm 4.21$ & $408.10 \pm 25.78$ \\
\hline $\mathrm{S}_{26}$ & $11^{\circ} 49^{\prime} 579^{\prime \prime} \mathrm{N}$ & $79^{\circ} 36^{\prime} 488^{\prime \prime} \mathrm{E}$ & 71.2 & 71.1 & 0.14 & $6.98 \pm 3.11$ & $59.68 \pm 4.44$ & $405.04 \pm 25.58$ \\
\hline $\mathrm{S}_{27}$ & $11^{\circ} 49^{\prime} 328^{\prime \prime} \mathrm{N}$ & $79^{\circ} 37^{\prime} 131^{\prime \prime} \mathrm{E}$ & 72.3 & 72.1 & 0.28 & $6.68 \pm 2.96$ & $58.69 \pm 5.26$ & $405.11 \pm 28.82$ \\
\hline $\mathrm{S}_{28}$ & $11^{\circ} 49^{\prime} 001^{\prime \prime} \mathrm{N}$ & $79^{\circ} 37^{\prime} 273^{\prime \prime} \mathrm{E}$ & 65.3 & 64.2 & 1.68 & $6.97 \pm 2.89$ & $68.59 \pm 5.01$ & $403.94 \pm 32.17$ \\
\hline $\mathrm{S}_{29}$ & $11^{\circ} 48^{\prime} 090^{\prime \prime} \mathrm{N}$ & $79^{\circ} 37^{\prime} 994^{\prime \prime} \mathrm{E}$ & 26.5 & 26.4 & 0.38 & $6.69 \pm 2.65$ & $70.96 \pm 6.18$ & $418.53 \pm 27.18$ \\
\hline $\mathrm{S}_{30}$ & $11^{\circ} 47^{\prime} 853^{\prime \prime} \mathrm{N}$ & $79^{\circ} 38^{\prime} 736^{\prime \prime} \mathrm{E}$ & 44.5 & 44.4 & 0.22 & $7.24 \pm 3.21$ & $74.52 \pm 6.11$ & $430.36 \pm 27.16$ \\
\hline $\mathrm{S}_{31}$ & $11^{\circ} 47^{\prime} 124^{\prime \prime} \mathrm{N}$ & $79^{\circ} 39^{\prime} 249^{\prime \prime} \mathrm{E}$ & 70.0 & 69.8 & 0.29 & $6.45 \pm 3.14$ & $78.36 \pm 6.25$ & $424.09 \pm 25.68$ \\
\hline $\mathrm{S}_{32}$ & $11^{\circ} 48^{\prime} 021^{\prime \prime} \mathrm{N}$ & $79^{\circ} 39^{\prime} 755^{\prime \prime} \mathrm{E}$ & 78.6 & 78.4 & 0.25 & $6.98 \pm 2.96$ & $87.23 \pm 6.54$ & $420.55 \pm 27.72$ \\
\hline $\mathrm{S}_{33}$ & $11^{\circ} 48^{\prime} 464^{\prime \prime} \mathrm{N}$ & $79^{\circ} 40^{\prime} 249^{\prime \prime} \mathrm{E}$ & 30.0 & 29.8 & 0.67 & $\mathrm{BDL}$ & $74.52 \pm 6.01$ & $424.72 \pm 32.57$ \\
\hline $\mathrm{S}_{34}$ & $11^{\circ} 47^{\prime} 414^{\prime \prime} \mathrm{N}$ & $79^{\circ} 41^{\prime} 792^{\prime \prime} \mathrm{E}$ & 89.0 & 84.1 & 5.51 & $6.68 \pm 2.65$ & $89.65 \pm 6.98$ & $434.59 \pm 28.69$ \\
\hline $\mathrm{S}_{35}$ & $11^{\circ} 47^{\prime} 549^{\prime \prime} \mathrm{N}$ & $79^{\circ} 42^{\prime} 287^{\prime \prime} \mathrm{E}$ & 182.0 & 169.1 & 7.09 & $6.57 \pm 2.56$ & $95.64 \pm 6.34$ & $426.24 \pm 30.18$ \\
\hline $\mathrm{S}_{36}$ & $11^{\circ} 47^{\prime} 482^{\prime \prime} \mathrm{N}$ & $79^{\circ} 42^{\prime} 758^{\prime \prime} \mathrm{E}$ & 178.8 & 169.2 & 5.37 & $\mathrm{BDL}$ & $96.64 \pm 6.24$ & $437.71 \pm 27.81$ \\
\hline $\mathrm{S}_{37}$ & $11^{\circ} 46^{\prime} 831^{\prime \prime} \mathrm{N}$ & $79^{\circ} 43^{\prime} 642^{\prime \prime} \mathrm{E}$ & 144.1 & 133.8 & 7.15 & $6.56 \pm 2.68$ & $94.65 \pm 6.21$ & $455.89 \pm 20.62$ \\
\hline $\mathrm{S}_{38}$ & $11^{\circ} 46^{\prime} 821^{\prime \prime} \mathrm{N}$ & $79^{\circ} 44^{\prime} 201^{\prime \prime} \mathrm{E}$ & 156.0 & 145.1 & 7.00 & $\mathrm{BDL}$ & $97.26 \pm 6.98$ & $442.09 \pm 25.68$ \\
\hline $\mathrm{S}_{39}$ & $11^{\circ} 46^{\prime} 405^{\prime \prime} \mathrm{N}$ & $79^{\circ} 45^{\prime} 821^{\prime \prime} \mathrm{E}$ & 260.1 & 246.3 & 5.31 & $6.59 \pm 2.87$ & $96.48 \pm 6.16$ & $454.21 \pm 22.32$ \\
\hline \multirow[t]{4}{*}{$\mathrm{S}_{40}$} & $11^{\circ} 45^{\prime} 350^{\prime \prime} \mathrm{N}$ & $79^{\circ} 47^{\prime} 685^{\prime \prime} \mathrm{E}$ & 259.0 & 248.6 & 4.02 & $6.52 \pm 2.98$ & $106.11 \pm 7.16$ & $467.71 \pm 22.54$ \\
\hline & \multicolumn{5}{|c|}{ | } & $7.31 \pm 3.41$ & $46.85 \pm 5.25$ & $384.11 \pm 26.82$ \\
\hline & \multirow{2}{*}{\multicolumn{5}{|c|}{$\begin{array}{l}\text { maximum } \\
\text { minimum }\end{array}$}} & $11.6 \pm 6.13$ & $106.11 \pm 7.16$ & $467.71 \pm 22.54$ \\
\hline & & & & & & $\mathrm{BDL}$ & $\mathrm{BDL}$ & $201.23 \pm 23.96$ \\
\hline
\end{tabular}


TABLE II

Absorbed dose rate, AEDE, $\mathrm{Ra}_{\mathrm{eq}}$ and hazard indices $\left(H_{\mathrm{ex}}, H_{\mathrm{in}}, I \gamma, I\right.$ and ELCR) of all sites.

\begin{tabular}{|c|c|c|c|c|c|c|c|c|c|}
\hline \multirow{2}{*}{$\begin{array}{c}\text { Site } \\
\text { number }\end{array}$} & \multirow{2}{*}{$\begin{array}{c}\text { Absorbed } \\
\text { dose rate } \\
{[\mathrm{nGy} / \mathrm{h}]}\end{array}$} & \multicolumn{2}{|c|}{$\operatorname{AEDE}[\mu \mathrm{Sv} / \mathrm{y}]$} & \multirow{2}{*}{$\begin{array}{c}\text { Raeq } \\
{[\mathrm{Bq} / \mathrm{kg}]}\end{array}$} & \multicolumn{5}{|c|}{ Hazard indices } \\
\hline & & indoor & outdoor & & $H_{\mathrm{ex}}$ & $H_{\text {in }}$ & $I \gamma$ & $I$ & $\begin{array}{c}\mathrm{ELCR} \\
{\left[\times 10^{-3}\right]}\end{array}$ \\
\hline $\mathrm{s}_{1}$ & $16.48 \pm 5.78$ & $80.82 \pm 28.34$ & $20.21 \pm 7.08$ & $33.74 \pm 12.76$ & $0.091 \pm 0.034$ & $0.117 \pm 0.046$ & $0.13 \pm 0.045$ & $0.28 \pm 0.083$ & $0.071 \pm 0.025$ \\
\hline $\mathrm{S}_{2}$ & $21.53 \pm 9.45$ & $105.64 \pm 46.34$ & $26.411 \pm 11.59$ & $43.64 \pm 21.24$ & $0.118 \pm 0.057$ & $0.149 \pm 0.103$ & $0.17 \pm 0.075$ & $0.41 \pm 0.151$ & $0.092 \pm 0.041$ \\
\hline $\mathrm{S}_{3}$ & $18.61 \pm 2.92$ & $91.27 \pm 14.33$ & $22.82 \pm 3.58$ & $37.25 \pm 5.98$ & $0.101 \pm 0.016$ & $0.117 \pm 0.043$ & $0.15 \pm 0.022$ & $0.40 \pm 0.069$ & $0.080 \pm 0.013$ \\
\hline $\mathrm{S}_{4}$ & $19.89 \pm 5.48$ & $97.56 \pm 26.87$ & $24.39 \pm 6.72$ & $40.18 \pm 12.04$ & $0.109 \pm 0.033$ & $0.125 \pm 0.060$ & $0.16 \pm 0.043$ & $0.40 \pm 0.077$ & $0.085 \pm 0.024$ \\
\hline $\mathrm{S}_{5}$ & $21.69 \pm 5.44$ & $106.41 \pm 26.68$ & $26.60 \pm 6.67$ & $43.98 \pm 11.94$ & $0.119 \pm 0.032$ & $0.135 \pm 0.060$ & $0.17 \pm 0.043$ & $0.43 \pm 0.076$ & $0.093 \pm 0.023$ \\
\hline $\mathrm{s}_{6}$ & $22.06 \pm 5.08$ & $108.23 \pm 24.91$ & $27.06 \pm 6.23$ & $44.39 \pm 11.14$ & $0.120 \pm 0.030$ & $0.134 \pm 0.055$ & $0.18 \pm 0.040$ & $0.47 \pm 0.070$ & $0.095 \pm 0.022$ \\
\hline $\mathrm{s}_{7}$ & $22.32 \pm 5.99$ & $109.49 \pm 29.40$ & $27.37 \pm 7.35$ & $45.41 \pm 13.05$ & $0.123 \pm 0.035$ & $0.139 \pm 0.062$ & $0.18 \pm 0.047$ & $0.43 \pm 0.082$ & $0.096 \pm 0.026$ \\
\hline $\mathrm{S}_{8}$ & $23.05 \pm 5.49$ & $113.08 \pm 26.93$ & $28.27 \pm 6.73$ & $46.45 \pm 12.06$ & $0.125 \pm 0.033$ & $0.140 \pm 0.056$ & $0.18 \pm 0.043$ & $0.49 \pm 0.077$ & $0.099 \pm 0.024$ \\
\hline $\mathrm{S}_{9}$ & $26.51 \pm 4.97$ & $130.07 \pm 24.40$ & $32.52 \pm 6.10$ & $53.74 \pm 10.86$ & $0.145 \pm 0.029$ & $0.159 \pm 0.052$ & $0.21 \pm 0.039$ & $0.55 \pm 0.068$ & $0.114 \pm 0.021$ \\
\hline $\mathrm{S}_{10}$ & $25.92 \pm 5.10$ & $127.14 \pm 25.01$ & $31.78 \pm 6.25$ & $52.42 \pm 11.18$ & $0.142 \pm 0.030$ & $0.157 \pm 0.056$ & $0.21 \pm 0.040$ & $0.54 \pm 0.071$ & $0.111 \pm 0.022$ \\
\hline $\mathrm{S}_{11}$ & $27.18 \pm 5.36$ & $133.32 \pm 26.30$ & $33.33 \pm 6.58$ & $55.23 \pm 11.78$ & $0.149 \pm 0.032$ & $0.165 \pm 0.059$ & $0.22 \pm 0.042$ & $0.55 \pm 0.075$ & $0.117 \pm 0.023$ \\
\hline $\mathrm{S}_{12}$ & $30.51 \pm 5.60$ & $149.67 \pm 27.45$ & $37.42 \pm 6.86$ & $63.59 \pm 12.39$ & $0.172 \pm 0.033$ & $0.188 \pm 0.059$ & $0.24 \pm 0.044$ & $0.53 \pm 0.082$ & $0.131 \pm 0.024$ \\
\hline $\mathrm{S}_{13}$ & $28.88 \pm 5.18$ & $141.67 \pm 25.41$ & $35.42 \pm 6.35$ & $59.25 \pm 11.39$ & $0.160 \pm 0.031$ & $0.174 \pm 0.057$ & $0.23 \pm 0.041$ & $0.55 \pm 0.073$ & $0.124 \pm 0.022$ \\
\hline $\mathrm{S}_{14}$ & $31.83 \pm 5.23$ & $156.17 \pm 25.64$ & $39.04 \pm 6.41$ & $66.42 \pm 11.51$ & $0.179 \pm 0.031$ & $0.193 \pm 0.056$ & $0.26 \pm 0.041$ & $0.56 \pm 0.074$ & $0.137 \pm 0.022$ \\
\hline $\mathrm{S}_{15}$ & $32.94 \pm 5.44$ & $161.59 \pm 26.71$ & $40.40 \pm 6.68$ & $69.57 \pm 12.00$ & $0.188 \pm 0.032$ & $0.203 \pm 0.059$ & $0.26 \pm 0.043$ & $0.55 \pm 0.077$ & $0.141 \pm 0.023$ \\
\hline $\mathrm{S}_{16}$ & $35.28 \pm 6.91$ & $173.08 \pm 33.89$ & $43.27 \pm 8.47$ & $74.52 \pm 15.13$ & $0.201 \pm 0.041$ & $0.216 \pm 0.059$ & $0.28 \pm 0.054$ & $0.60 \pm 0.101$ & $0.151 \pm 0.030$ \\
\hline $\mathrm{s}_{17}$ & $34.59 \pm 5.68$ & $169.69 \pm 27.88$ & $42.42 \pm 6.97$ & $72.98 \pm 12.52$ & $0.197 \pm 0.034$ & $0.211 \pm 0.055$ & $0.28 \pm 0.045$ & $0.59 \pm 0.080$ & $0.148 \pm 0.024$ \\
\hline $\mathrm{S}_{18}$ & $37.45 \pm 5.62$ & $183.74 \pm 27.57$ & $45.93 \pm 6.89$ & $79.56 \pm 12.38$ & $0.215 \pm 0.033$ & $0.229 \pm 0.057$ & $0.30 \pm 0.044$ & $0.63 \pm 0.080$ & $0.161 \pm 0.024$ \\
\hline $\mathrm{S}_{19}$ & $40.18 \pm 5.80$ & $197.11 \pm 28.43$ & $49.28 \pm 7.11$ & $85.99 \pm 12.77$ & $0.232 \pm 0.034$ & $0.247 \pm 0.060$ & $0.32 \pm 0.046$ & $0.67 \pm 0.082$ & $0.172 \pm 0.025$ \\
\hline $\mathrm{S}_{20}$ & $42.68 \pm 5.61$ & $209.35 \pm 27.53$ & $52.34 \pm 6.88$ & $91.76 \pm 12.40$ & $0.248 \pm 0.033$ & $0.261 \pm 0.058$ & $0.35 \pm 0.045$ & $0.73 \pm 0.082$ & $0.183 \pm 0.024$ \\
\hline $\mathrm{S}_{21}$ & $42.48 \pm 5.70$ & $208.40 \pm 27.94$ & $52.10 \pm 6.99$ & $91.52 \pm 12.61$ & $0.247 \pm 0.034$ & $0.261 \pm 0.059$ & $0.34 \pm 0.045$ & $0.72 \pm 0.083$ & $0.182 \pm 0.024$ \\
\hline $\mathrm{S}_{22}$ & $45.58 \pm 6.08$ & $223.61 \pm 29.82$ & $55.90 \pm 7.45$ & $98.56 \pm 13.45$ & $0.266 \pm 0.036$ & $0.280 \pm 0.061$ & $0.37 \pm 0.048$ & $0.78 \pm 0.089$ & $0.196 \pm 0.026$ \\
\hline $\mathrm{S}_{23}$ & $49.42 \pm 6.06$ & $242.42 \pm 29.74$ & $60.60 \pm 7.43$ & $107.59 \pm 13.48$ & $0.291 \pm 0.036$ & $0.304 \pm 0.060$ & $0.40 \pm 0.048$ & $0.86 \pm 0.093$ & $0.212 \pm 0.026$ \\
\hline $\mathrm{S}_{24}$ & $55.39 \pm 4.95$ & $271.70 \pm 24.26$ & $67.93 \pm 6.06$ & $121.66 \pm 10.76$ & $0.329 \pm 0.029$ & $0.341 \pm 0.052$ & $0.45 \pm 0.039$ & $1.00 \pm 0.068$ & $0.238 \pm 0.021$ \\
\hline $\mathrm{S}_{25}$ & $60.10 \pm 4.86$ & $294.83 \pm 23.84$ & $73.71 \pm 5.96$ & $132.80 \pm 10.70$ & $0.359 \pm 0.029$ & $0.371 \pm 0.052$ & $0.49 \pm 0.039$ & $1.12 \pm 0.069$ & $0.258 \pm 0.021$ \\
\hline $\mathrm{S}_{26}$ & $56.16 \pm 5.19$ & $275.51 \pm 25.44$ & $68.88 \pm 6.36$ & $123.51 \pm 11.43$ & $0.333 \pm 0.031$ & $0.347 \pm 0.055$ & $0.46 \pm 0.041$ & $1.02 \pm 0.074$ & $0.241 \pm 0.022$ \\
\hline $\mathrm{S}_{27}$ & $55.43 \pm 5.75$ & $271.91 \pm 28.19$ & $67.98 \pm 7.05$ & $121.80 \pm 12.70$ & $0.329 \pm 0.034$ & $0.342 \pm 0.057$ & $0.45 \pm 0.046$ & $1.01 \pm 0.084$ & $0.238 \pm 0.025$ \\
\hline $\mathrm{S}_{28}$ & $61.49 \pm 5.70$ & $301.66 \pm 27.98$ & $75.41 \pm 6.99$ & $136.16 \pm 12.53$ & $0.368 \pm 0.034$ & $0.381 \pm 0.058$ & $0.50 \pm 0.045$ & $1.15 \pm 0.082$ & $0.264 \pm 0.024$ \\
\hline $\mathrm{S}_{29}$ & $63.40 \pm 6.09$ & $311.03 \pm 29.88$ & $77.76 \pm 7.47$ & $140.39 \pm 13.58$ & $0.379 \pm 0.037$ & $0.392 \pm 0.060$ & $0.52 \pm 0.049$ & $1.20 \pm 0.097$ & $0.272 \pm 0.026$ \\
\hline $\mathrm{S}_{30}$ & $66.30 \pm 6.31$ & $325.25 \pm 30.93$ & $81.31 \pm 7.73$ & $146.94 \pm 14.04$ & $0.397 \pm 0.038$ & $0.411 \pm 0.063$ & $0.54 \pm 0.050$ & $1.25 \pm 0.096$ & $0.285 \pm 0.027$ \\
\hline $\mathrm{S}_{31}$ & $68.46 \pm 6.30$ & $335.82 \pm 30.89$ & $83.95 \pm 7.72$ & $152.16 \pm 14.05$ & $0.411 \pm 0.038$ & $0.426 \pm 0.064$ & $0.56 \pm 0.050$ & $1.31 \pm 0.098$ & $0.294 \pm 0.027$ \\
\hline $\mathrm{S}_{32}$ & $73.45 \pm 6.47$ & $360.31 \pm 31.76$ & $90.08 \pm 7.94$ & $164.10 \pm 14.45$ & $0.443 \pm 0.039$ & $0.457 \pm 0.063$ & $0.60 \pm 0.052$ & $1.46 \pm 0.102$ & $0.315 \pm 0.028$ \\
\hline $\mathrm{S}_{33}$ & $65.72 \pm 4.99$ & $322.42 \pm 24.47$ & $80.60 \pm 6.12$ & $145.77 \pm 11.10$ & $0.394 \pm 0.030$ & $0.406 \pm 0.060$ & $0.54 \pm 0.041$ & $1.26 \pm 0.105$ & $0.282 \pm 0.021$ \\
\hline $\mathrm{S}_{34}$ & $75.36 \pm 6.64$ & $369.67 \pm 32.56$ & $92.42 \pm 8.14$ & $168.34 \pm 14.84$ & $0.455 \pm 0.040$ & $0.467 \pm 0.064$ & $0.62 \pm 0.053$ & $1.50 \pm 0.109$ & $0.323 \pm 0.028$ \\
\hline $\mathrm{S}_{35}$ & $78.58 \pm 6.27$ & $385.46 \pm 30.76$ & $96.37 \pm 7.69$ & $176.16 \pm 13.95$ & $0.476 \pm 0.038$ & $0.488 \pm 0.061$ & $0.64 \pm 0.050$ & $1.60 \pm 0.099$ & $0.337 \pm 0.027$ \\
\hline $\mathrm{S}_{36}$ & $79.63 \pm 4.93$ & $390.61 \pm 24.18$ & $97.65 \pm 6.04$ & $178.40 \pm 11.06$ & $0.482 \pm 0.030$ & $0.494 \pm 0.060$ & $0.65 \pm 0.040$ & $1.62 \pm 0.109$ & $0.342 \pm 0.021$ \\
\hline $\mathrm{S}_{37}$ & $79.21 \pm 5.85$ & $388.57 \pm 28.69$ & $97.14 \pm 7.17$ & $177.01 \pm 13.15$ & $0.478 \pm 0.036$ & $0.490 \pm 0.058$ & $0.65 \pm 0.047$ & $1.59 \pm 0.097$ & $0.340 \pm 0.025$ \\
\hline $\mathrm{S}_{38}$ & $80.18 \pm 5.29$ & $393.35 \pm 25.93$ & $98.34 \pm 6.48$ & $179.62 \pm 11.96$ & $0.485 \pm 0.032$ & $0.497 \pm 0.062$ & $0.66 \pm 0.043$ & $1.63 \pm 0.122$ & $0.344 \pm 0.023$ \\
\hline $\mathrm{s}_{39}$ & $80.82 \pm 5.98$ & $396.48 \pm 29.32$ & $99.12 \pm 7.33$ & $180.57 \pm 13.40$ & $0.488 \pm 0.036$ & $0.500 \pm 0.059$ & $0.66 \pm 0.048$ & $1.62 \pm 0.096$ & $0.347 \pm 0.026$ \\
\hline $\mathrm{S}_{40}$ & $86.17 \pm 6.64$ & $422.73 \pm 32.58$ & $105.68 \pm 8.14$ & $193.47 \pm 14.95$ & $0.522 \pm 0.040$ & $0.535 \pm 0.062$ & $0.70 \pm 0.053$ & $1.79 \pm 0.112$ & $0.370 \pm 0.029$ \\
\hline average & $47.07 \pm 5.20$ & $230.92 \pm 27.98$ & $57.73 \pm 6.99$ & $102.42 \pm 12.61$ & $0.277 \pm 0.034$ & $0.291 \pm 0.060$ & $0.38 \pm 0.045$ & $0.90 \pm 0.088$ & $0.202 \pm 0.024$ \\
\hline maximum & $86.17 \pm 6.64$ & $422.73 \pm 32.58$ & $105.68 \pm 8.14$ & $193.47 \pm 14.95$ & $0.522 \pm 0.040$ & $0.535 \pm 0.062$ & $0.70 \pm 0.053$ & $1.79 \pm 0.112$ & $0.370 \pm 0.029$ \\
\hline minimum & $16.48 \pm 5.78$ & $80.82 \pm 28.34$ & $20.21 \pm 7.08$ & $33.74 \pm 12.76$ & $0.091 \pm 0.036$ & $0.117 \pm 0.043$ & $0.13 \pm 0.045$ & $0.28 \pm 0.083$ & $0.071 \pm 0.025$ \\
\hline
\end{tabular}

\subsection{Radium equivalent activities $\left(R a_{\mathrm{eq}}\right)$}

The radium equivalent concept allows a single index or number to describe the gamma output from different mixtures of uranium, thorium and potassium in the sediments sampled from different locations. It is a widely used hazard index and is calculated using the equation below [28]:

$$
\mathrm{Ra}_{\mathrm{eq}}[\mathrm{Bq} / \mathrm{kg}]=C_{\mathrm{U}}+1.43 C_{\mathrm{Th}}+0.077 C_{\mathrm{K}},
$$

where $C_{\mathrm{U}}, C_{\mathrm{Th}}$, and $C_{\mathrm{K}}$ are the mean activity concentrations of ${ }^{238} \mathrm{U},{ }^{232} \mathrm{Th}$, and ${ }^{40} \mathrm{~K}$ in $\mathrm{Bq} / \mathrm{kg}$, respectively. Table II summarizes the value of $\mathrm{Ra}_{\mathrm{eq}}$. These values varied from 33.74 to $193.47 \mathrm{~Bq} / \mathrm{kg}$ with an average of $102.41 \mathrm{~Bq} / \mathrm{kg}$. The estimated average values of $\mathrm{Ra}_{\mathrm{eq}}$ in this study are lower than the recommended maximum value of $370 \mathrm{~Bq} / \mathrm{kg}$ for the safe use of materials in the construction of buildings [6]. Agreement has been observed between the detected $\mathrm{Ra}_{\mathrm{eq}}$ with the soils of Jordan $\left(\mathrm{Ra}_{\mathrm{eq}}=103 \mathrm{~Bq} / \mathrm{kg}\right)$ [29]. Lower $\mathrm{Ra}_{\mathrm{eq}}$ of this study may be due to the leaching of heavy minerals by continuous flow of water in the river.

\subsection{Hazard indices $\left(H_{\mathrm{ex}}\right.$ and $\left.H_{\mathrm{in}}\right)$}

Beretka and Mathew [30] defined two indices that represent external and internal radiation hazards. The prime objective of these indices is to limit the radiation dose to dose equivalent limit of $1 \mathrm{mSv} / \mathrm{y}$. The external hazard index $\left(H_{\mathrm{ex}}\right)$ is calculated using the given equation:

$$
H_{\mathrm{ex}}=\left(C_{\mathrm{U}} / 370+C_{\mathrm{Th}} / 259+C_{\mathrm{K}} / 4810\right) \leq 1,
$$

where $C_{\mathrm{U}}, C_{\mathrm{Th}}$, and $C_{\mathrm{K}}$ are the mean activity concentrations of ${ }^{238} \mathrm{U},{ }^{232} \mathrm{Th}$, and ${ }^{40} \mathrm{~K}$ in $\mathrm{Bq} / \mathrm{kg}$, respectively. 
$H_{\mathrm{ex}}$ must not exceed the limit of unity for the radiation hazard to be negligible. On the other hand, the internal hazard index $\left(H_{\text {in }}\right)$ gives the internal exposure to carcinogenic radon and its short-lived progency and is given by the following formula $[28,30]$ :

$$
H_{\text {in }}=\left(C_{\mathrm{U}} / 185+C_{\mathrm{Th}} / 259+C_{\mathrm{K}} / 4810\right)<1,
$$

where $C_{\mathrm{U}}, C_{\mathrm{Th}}$ and $C_{\mathrm{K}}$ are the mean activity concentrations of ${ }^{238} \mathrm{U},{ }^{232} \mathrm{Th}$, and ${ }^{40} \mathrm{~K}$ in $\mathrm{Bq} / \mathrm{kg}$, respectively. The value of $H_{\text {in }}$ must also be less than unity to have negligible hazardous effects of radon and its short-lived progency to the respiratory organs [6]. The calculated values of these indices are given in Table II. Thus, the hazard indices of all site samples are less than unity (permissible level) [27].

\subsection{Gamma index $(I \gamma)$}

Gamma index deals with the assessment of excess gamma radiation originating from building materials (river sediment). It takes into account typical ways and quantities in which the materials are used in buildings.

In this study, the gamma index is calculated using the below equation as proposed by European commission [31]. The value of gamma index depends on the dose criterion and the mode and quantity of the materials used in a building. As is suggested by the European commission for the materials used in bulk amounts, the exemption dose criterion $(0.3 \mathrm{mSv} / \mathrm{y})$ corresponds to $I \gamma \leq 0.5$, whereas the dose criterion $1 \mathrm{mSv} / \mathrm{y}$ corresponds to $I \gamma \leq 1$ [31]. On the other hand, for superficial and other materials with restricted use the corresponding values of $I \gamma$ should be: $I \gamma<2$ and $I \gamma<6$, respectively,

$$
I \gamma=C_{\mathrm{U}} / 300+C_{\mathrm{Th}} / 200+C_{\mathrm{K}} / 3000,
$$

where $C_{\mathrm{U}}, C_{\mathrm{Th}}$, and $C_{\mathrm{K}}$ are the mean activity concentrations of ${ }^{238} \mathrm{U},{ }^{232} \mathrm{Th}$, and ${ }^{40} \mathrm{~K}$ in $\mathrm{Bq} / \mathrm{kg}$, respectively, in sediments. Calculated $I \gamma$ values for all sites are given in Table II. The ranges of $I \gamma$ are $0.13-0.70$ with an average of 0.38 . No exceedance of the recommended upper limit is noted, but last 11 locations $\left(\mathrm{S}_{29}\right.$ to $\left.\mathrm{S}_{40}\right)$ exceeded the recommended exemption level for exposure to external gamma radiation. However, average value of $I \gamma$ is lower than the values of other studies conducted from other countries $[32,33]$. The average relative contribution to gamma index due to the ${ }^{232} \mathrm{Th}$ is $51.2 \%$ followed by the contributions due to the ${ }^{40} \mathrm{~K}$ and ${ }^{238} \mathrm{U}(40.15 \%$ and $8.6 \%$, respectively). This means that, generally ${ }^{238} \mathrm{U}$, ${ }^{232} \mathrm{Th}$, and ${ }^{40} \mathrm{~K}$ contributed similarly to external exposure; only in few cases, one of these radionuclides play a predominant role. This happened in last 11 locations $\left(\mathrm{S}_{29}\right.$ to $\left.\mathrm{S}_{40}\right)$.

\subsection{Activity utilization index (I)}

Since river sediments are used as building construction materials, the Ponnaiyar river sediments are also examined whether it is used as building materials or not. Calculation of activity utilization index $(I)$ has been calculated for this reason using the below equation given by
Tzortzis and Tsertos [32] and El-Gamal et al. [9]:

$$
I=\left(C_{\mathrm{U}} / 50\right) f_{\mathrm{U}}+\left(C_{\mathrm{Th}} / 50\right) f_{\mathrm{Th}}+\left(C_{\mathrm{K}} / 500\right) f_{\mathrm{K}},
$$

where $C_{\mathrm{U}}, C_{\mathrm{Th}}$, and $C_{\mathrm{K}}$ are the mean activity concentrations of ${ }^{238} \mathrm{U},{ }^{232} \mathrm{Th}$, and ${ }^{40} \mathrm{~K}$ in $\mathrm{Bq} / \mathrm{kg}$, respectively, in sediments. $f_{\mathrm{U}}, f_{\mathrm{Th}}$, and $f_{\mathrm{K}}$ are the fractional contribution to the total dose rate of ${ }^{238} \mathrm{U},{ }^{232} \mathrm{Th}$, and ${ }^{40} \mathrm{~K}$, respectively. The calculated values are documented in Table II. The values ranged from 0.28 to 1.79 with an average of 0.90 , exhibit that $I<2$, which corresponds to an annual effective dose $<0.3 \mathrm{mSv} / \mathrm{y}$ [9]. This indicates that the Ponnaiyar river sediments can be used for safety construction of buildings. The mean value of this study is higher than the values for river sediments from Nile river, Egypt [9].

\subsection{Excess lifetime cancer risk}

Excess lifetime cancer risk (ELCR) is calculated using below equation and shown in Table II

$\mathrm{ELCR}=\mathrm{AEDE} \times \mathrm{DL} \times \mathrm{RF}$,

where AEDE, DL, and RF is the annual effective dose equivalent, duration of life (70 years) and risk factor $\left(\mathrm{Sv}^{-1}\right)$, fatal cancer risk per sievert. For stochastic effects, ICRP 60 uses values of 0.05 for the public [7].

The obtained range of ELCR is $0.071 \times 10^{-3}$ to $0.37 \times$ $10^{-3}$ with an average of $0.202 \times 10^{-3}$. This average ELCR is less than the world average $\left(0.29 \times 10^{-3}\right)[6]$. The last eight sampling sites have higher ELCR value $\left(S_{33}\right.$ to $\left.S_{40}\right)$. However, the average ELCR value of present sediments is lower than the values obtained by Taskin et al. [7] for soil samples of Turkey.

\section{Mineralogical characterization of the sediments}

Frequencies $\left(\mathrm{cm}^{-1}\right)$ obtained from recorded spectra of all samples are tabulated with corresponding minerals in Table III. A selected representative FTIR spectrum (site number $\mathrm{S}_{6}$ ) is shown in Fig. 2. The minerals such as quartz, microcline feldspar, orthoclase feldspar, kaolinite, calcite, gibbsite, montmorillonite, smectite, palygorskite and organic carbon are identified by comparing the observed wave numbers with available literature [20, 34].

Quartz is one of the non-clay minerals and is invariably present in all samples. The presence of quartz in the samples can be explained by $\mathrm{Si}-\mathrm{O}$ asymmetrical bending vibrations around $462 \mathrm{~cm}^{-1}, \mathrm{Si}-\mathrm{O}$ symmetrical bending vibrations around $694 \mathrm{~cm}^{-1}, \mathrm{Si}-\mathrm{O}$ symmetrical stretching vibrations at around 778 and $796 \mathrm{~cm}^{-1}$, while the 1082 and $1162 \mathrm{~cm}^{-1}$ absorption region arises from $\mathrm{Si}-\mathrm{O}$ asymmetrical stretching vibrations due to low $\mathrm{Al}$ for $\mathrm{Si}$ substitution.

Feldspar is also a frequent constituent in sediments. This group of minerals contains several types such as orthoclase, microcline, sanidine (K-feldspar), albite (Na-feldspar) and anorthite (Ca-feldspar). Though three feldspars (orthoclase, microcline and sanidine) are having 
the same chemical formula $\left(\mathrm{KAlSi}_{3} \mathrm{O}_{8}\right)$, they have different structures (orthoclase-monocline, microcline-triclinic and sanidine-tetrahedral). The peak corresponding to the range $583-587 \mathrm{~cm}^{-1}$ is due to the $\mathrm{O}-\mathrm{Si}-(\mathrm{Al})-\mathrm{O}$ bend- ing vibration for microcline and in the range 647-650 and $532-537 \mathrm{~cm}^{-1}$ is due to the $\mathrm{Al}-\mathrm{O}$ coordination vibrations indicates the presence of orthoclase feldspar [20].

TABLE III

The observed absorption wave numbers and corresponding minerals from FTIR spectra.

\begin{tabular}{|c|c|c|c|}
\hline S. No. & Mineral name & Site number & $\begin{array}{l}\text { Observed wave } \\
\text { numbers }\left[\mathrm{cm}^{-1}\right]\end{array}$ \\
\hline \multirow{8}{*}{1} & \multirow{8}{*}{ quartz } & $\mathrm{S}_{1}-\mathrm{S}_{40}$ & $460-464$ \\
\hline & & $\mathrm{S}_{1}-\mathrm{S}_{40}$ & $514-520$ \\
\hline & & $\mathrm{S}_{1}-\mathrm{S}_{40}$ & $693-694$ \\
\hline & & $\mathrm{S}_{1}-\mathrm{S}_{40}$ & $777-778$ \\
\hline & & $\mathrm{S}_{1}-\mathrm{S}_{40}$ & $794-796$ \\
\hline & & $\mathrm{S}_{1}-\mathrm{S}_{40}$ & $1080-1084$ \\
\hline & & $\mathrm{S}_{1}-\mathrm{S}_{40}$ & $1162-1164$ \\
\hline & & $\mathrm{S}_{6}, \mathrm{~S}_{9}, \mathrm{~S}_{13}-\mathrm{S}_{19}, \mathrm{~S}_{22}, \mathrm{~S}_{31}, \mathrm{~S}_{35}-\mathrm{S}_{37}$ & $1615-1620$ \\
\hline 2 & microcline feldspar & $\mathrm{S}_{1}-\mathrm{S}_{40}$ & $583-587$ \\
\hline \multirow{2}{*}{3} & \multirow{2}{*}{ orthoclase feldspar } & $\mathrm{S}_{1}-\mathrm{S}_{10}, \mathrm{~S}_{13}-\mathrm{S}_{40}$ & $647-650$ \\
\hline & & $\mathrm{S}_{1}, \mathrm{~S}_{3}, \mathrm{~S}_{15}, \mathrm{~S}_{21}, \mathrm{~S}_{23}, \mathrm{~S}_{29}$ & $532-537$ \\
\hline \multirow{4}{*}{4} & \multirow{4}{*}{ kaolinite } & $\mathrm{S}_{1}-\mathrm{S}_{40}$ & $1015-1019$ \\
\hline & & $\mathrm{S}_{1}, \mathrm{~S}_{3}, \mathrm{~S}_{10}, \mathrm{~S}_{15}$ & $1030-1037$ \\
\hline & & $\mathrm{S}_{6}, \mathrm{~S}_{10}, \mathrm{~S}_{15}-\mathrm{S}_{19}, \mathrm{~S}_{24}, \mathrm{~S}_{32}, \mathrm{~S}_{35}-\mathrm{S}_{36}$ & $3618-3622$ \\
\hline & & $\mathrm{S}_{1}, \mathrm{~S}_{2}, \mathrm{~S}_{23}, \mathrm{~S}_{33}, \mathrm{~S}_{29}, \mathrm{~S}_{34}$ & $3690-3691$ \\
\hline 5 & gibbsite & $\mathrm{S}_{1}-\mathrm{S}_{40}$ & $662-670$ \\
\hline 6 & calcite & $\mathrm{S}_{2}, \mathrm{~S}_{3}, \mathrm{~S}_{4}, \mathrm{~S}_{33}, \mathrm{~S}_{36}$ & $1420-1438$ \\
\hline 7 & montmorillonite & $\mathrm{S}_{36}$ & 878 \\
\hline 8 & palygorskite & $\mathrm{S}_{1}, \mathrm{~S}_{7}, \mathrm{~S}_{21}, \mathrm{~S}_{33}, \mathrm{~S}_{29}, \mathrm{~S}_{36}$ & $3611-3615$ \\
\hline 0 & orcanic carbon & $\mathrm{S}_{1}-\mathrm{S}_{40}$ & $2923-2929$ \\
\hline 9 & OIgante cartuont & $\mathrm{S}_{1}-\mathrm{S}_{40}$ & $2852-2865$ \\
\hline 10 & smectite & $\mathrm{S}_{27}$ & 523 \\
\hline
\end{tabular}

Correlation table. Strong correlation is given in bold face.

TABLE V

\begin{tabular}{c|c|c|c|c|c|c|c|c}
\hline \hline & ${ }^{238} \mathrm{U}$ & ${ }^{232} \mathrm{Th}$ & ${ }^{40} \mathrm{~K}$ & DOSE & MS & E-Q & E-MCF & E-KA \\
\hline${ }^{238} \mathrm{U}$ & 1.000 & & & & & & & \\
${ }^{232} \mathrm{Th}$ & -0.623 & 1.000 & & & & & & \\
${ }^{40} \mathrm{~K}$ & -0.769 & 0.818 & 1.000 & & & & & \\
$\mathrm{DOSE}$ & -0.638 & 0.999 & 0.847 & 1.000 & & & & \\
$\mathrm{MS}$ & -0.258 & $\mathbf{0 . 6 0 3}$ & 0.485 & $\mathbf{0 . 6 0 4}$ & 1.000 & & & \\
$\mathrm{E}-\mathrm{Q}$ & -0.107 & -0.089 & -0.076 & -0.093 & -0.098 & 1.000 & & \\
$\mathrm{E}-\mathrm{MCF}$ & -0.098 & -0.118 & -0.061 & -0.118 & -0.302 & 0.116 & 1.000 & \\
$\mathrm{E}-\mathrm{KA}$ & -0.822 & $\mathbf{0 . 8 5 2}$ & $\mathbf{0 . 9 2 2}$ & $\mathbf{0 . 8 6 9}$ & $\mathbf{0 . 5 0 0}$ & 0.075 & -0.005 & 1.000 \\
\hline
\end{tabular}

${ }^{238} \mathrm{U},{ }^{232} \mathrm{Th}$ and ${ }^{40} \mathrm{~K}$ are the concentrations of natural radionuclides $(\mathrm{Bq} / \mathrm{kg})$; DOSE — absorbed dose rate $(\mathrm{nGy} / \mathrm{h})$. MS - magnetic susceptibility $\left(\times 10^{-8} \mathrm{~m}^{3} / \mathrm{kg}\right)$; E-Q - extinction coefficient of quartz; E-MCF - extinction coefficient of microcline feldspar, and E-KA - extinction coefficient of kaolinite.

Kaolinite is the clay mineral. The presence of absorption band at or around 3690,3620, 1030 and $1015 \mathrm{~cm}^{-1}$ indicate the presence of clay mineral constituents as kaolinite [20]. The intensity of the bands varies from sample to sample which indicates its quantity. According to Russell [34], if four peaks are observed in the re- 
gion $3697-3620 \mathrm{~cm}^{-1}$, the minerals are said to be ordered state. However, in the present study only two peaks are observed at 3690 and $3620 \mathrm{~cm}^{-1}$ in some sites. This suggests that the minerals may be in disordered state.

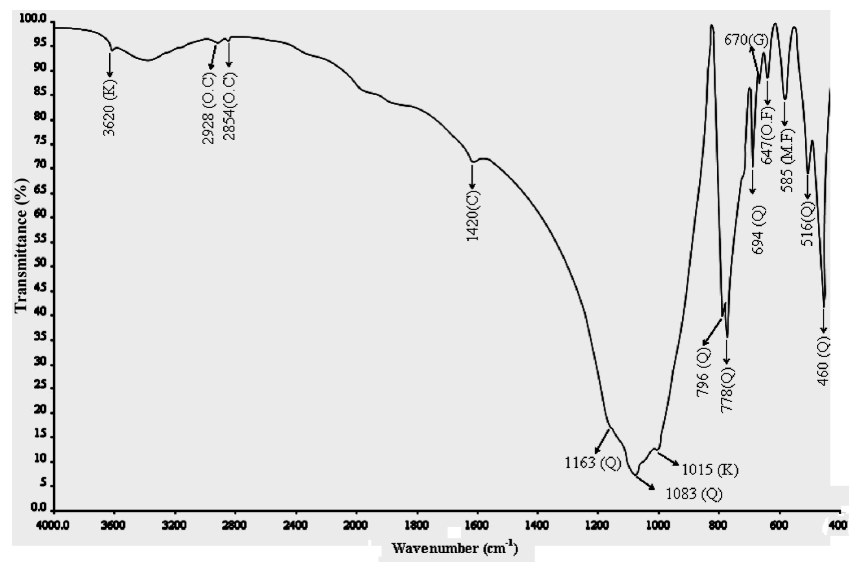

Fig. 2. FTIR spectrum of sediment sample of site number $\mathrm{S}_{6} . \mathrm{Q}-$ quartz, O.F - orthoclase feldspar, M.F - microcline feldspar, $\mathrm{K}$ - kaolinite, $\mathrm{C}$ - calcite, $\mathrm{G}$ - gibbsite, O.C — organic carbon.

Calcite is the most common carbonate mineral in sediments. From the existence of a peak in the range $1420-1438 \mathrm{~cm}^{-1}$ it is easily recognized that the calcite is present in site no. $\mathrm{S}_{2}-\mathrm{S}_{4}, \mathrm{~S}_{33}$ and $\mathrm{S}_{36}$. The existence of a peak near $665,878,523,2925,2855$, and $3612 \mathrm{~cm}^{-1}$, respectively, indicates presence of gibbsite, montmorillonite, smectite, organic Carbon and palygorskite.

With reference to the number of peaks and intensity, the minerals such as quartz, microcline feldspar and kaolinite are considered as major or main minerals. The other minerals are accessory. Therefore, the author is interested to study the relative distribution of quartz, microcline feldspar and kaolinite in Ponnaiyar River sediments. The relative distribution of major minerals can be quantified by calculating the extinction coefficient for the characteristic peaks of quartz, microcline feldspar, and kaolinite at around 778,585 , and $1015 \mathrm{~cm}^{-1}$, respectively, for all sites using the formula [20]. From the calculated values (Table IV), maximum extinction coefficient values for quartz, microcline feldspar, and kaolinite are $275.75,46.43$, and 5.16 in the sites no. $\mathrm{S}_{25}, \mathrm{~S}_{18}$, and $\mathrm{S}_{40}$, respectively. In the same way, minimum values are $35.68,6.65$, and 1.10 in the sites no. $\mathrm{S}_{36}, \mathrm{~S}_{28}$, and $\mathrm{S}_{1}$, respectively. With the maximum and minimum limits of the above said minerals, the other sites may be arranged for the containment of the same mineral quantitatively in an order. In overall view, the amount of kaolinite is lesser than microcline feldspar and very much lesser than quartz. Amount of quartz and microcline feldspar are randomly decreased and kaolinite is gradually increased towards the mouth of the river.
TABLE IV

The extinction coefficient of major minerals of all sites.

\begin{tabular}{|c|c|c|c|}
\hline \multirow{2}{*}{ Site number } & \multicolumn{3}{|c|}{ Extinction coefficient } \\
\hline & Quartz & Microcline feldspar & Kaolinite \\
\hline $\mathrm{S}_{1}$ & 92.65 & 26.65 & 1.10 \\
\hline $\mathrm{S}_{2}$ & 40.91 & 6.73 & 1.19 \\
\hline $\mathrm{S}_{3}$ & 171.82 & 26.83 & 2.29 \\
\hline $\mathrm{S}_{4}$ & 156.53 & 6.65 & 2.52 \\
\hline $\mathrm{S}_{5}$ & 77.25 & 13.55 & 2.87 \\
\hline $\mathrm{S}_{6}$ & 137.30 & 18.92 & 3.05 \\
\hline $\mathrm{S}_{7}$ & 107.01 & 15.58 & 3.10 \\
\hline $\mathrm{S}_{8}$ & 139.57 & 17.15 & 3.08 \\
\hline $\mathrm{S}_{9}$ & 95.70 & 18.69 & 3.10 \\
\hline $\mathrm{S}_{10}$ & 147.14 & 34.99 & 3.16 \\
\hline $\mathrm{S}_{11}$ & 110.38 & 6.81 & 3.22 \\
\hline $\mathrm{S}_{12}$ & 107.01 & 17.04 & 3.30 \\
\hline $\mathrm{S}_{13}$ & 92.31 & 15.29 & 3.39 \\
\hline $\mathrm{S}_{14}$ & 62.06 & 8.39 & 3.17 \\
\hline $\mathrm{S}_{15}$ & 153.10 & 29.83 & 3.73 \\
\hline $\mathrm{S}_{16}$ & 127.93 & 6.65 & 3.82 \\
\hline $\mathrm{S}_{17}$ & 49.35 & 20.58 & 3.22 \\
\hline $\mathrm{S}_{18}$ & 112.09 & 46.43 & 3.92 \\
\hline $\mathrm{S}_{19}$ & 210.10 & 24.02 & 4.88 \\
\hline $\mathrm{S}_{20}$ & 106.21 & 37.10 & 4.25 \\
\hline $\mathrm{S}_{21}$ & 165.43 & 27.45 & 4.01 \\
\hline $\mathrm{S}_{22}$ & 111.24 & 8.39 & 4.03 \\
\hline $\mathrm{S}_{23}$ & 70.63 & 11.82 & 4.03 \\
\hline $\mathrm{S}_{24}$ & 132.11 & 42.84 & 4.09 \\
\hline $\mathrm{S}_{25}$ & 275.75 & 8.33 & 4.19 \\
\hline $\mathrm{S}_{26}$ & 47.67 & 20.45 & 4.24 \\
\hline $\mathrm{S}_{27}$ & 127.23 & 29.64 & 4.25 \\
\hline $\mathrm{S}_{28}$ & 141.86 & 6.65 & 4.32 \\
\hline $\mathrm{S}_{29}$ & 45.98 & 22.23 & 4.33 \\
\hline $\mathrm{S}_{30}$ & 112.9 & 34.99 & 4.42 \\
\hline $\mathrm{S}_{31}$ & 171.82 & 8.44 & 4.48 \\
\hline $\mathrm{S}_{32}$ & 71.64 & 25.82 & 4.57 \\
\hline $\mathrm{S}_{33}$ & 159.2 & 15.19 & 4.68 \\
\hline $\mathrm{S}_{34}$ & 108.66 & 24.17 & 4.69 \\
\hline $\mathrm{S}_{35}$ & 181.57 & 17.26 & 4.79 \\
\hline $\mathrm{S}_{36}$ & 35.68 & 10.03 & 5.01 \\
\hline $\mathrm{S}_{37}$ & 88.88 & 13.38 & 4.95 \\
\hline $\mathrm{S}_{38}$ & 71.13 & 8.28 & 4.97 \\
\hline $\mathrm{S}_{39}$ & 66.31 & 6.65 & 5.07 \\
\hline $\mathrm{S}_{40}$ & 78.36 & 10.25 & 5.16 \\
\hline
\end{tabular}




\section{Correlation analysis}

In order to determine interrelation between the radioactivity and other measurements (magnetic susceptibility and mineralogical) in the sediments, the Pearson correlation analysis is carried out using SPSS for windows 16.0 software, and is presented in Table $\mathrm{V}$ as the linear correlation matrix. The correlation between the activity concentrations of ${ }^{238} \mathrm{U}$ and ${ }^{232} \mathrm{Th}$ is negative. Since the ${ }^{238} \mathrm{U}$ and ${ }^{232} \mathrm{Th}$ series occur commonly together in nature and this negative correlation may be due to soil process that affects differently the mobility of the two radionuclides [29]. This negative correlation indicates that the presence of monazite mineral in Ponnaiyar river sediments is less likely. Again negative correlation is obtained between the ${ }^{238} \mathrm{U}$ and ${ }^{40} \mathrm{~K}$ with correlation coefficient of -0.76 , whereas a positive correlation is observed between the ${ }^{232} \mathrm{Th}$ and ${ }^{40} \mathrm{~K}$ with correlation coefficient of 0.81 . The same positive correlation was fixed between the ${ }^{232} \mathrm{Th}$ and ${ }^{40} \mathrm{~K}$ by Krmar et al. [8] for Danube river sediments. This may be due to the increase of clay content.

The magnetic susceptibility is positively correlated with absorbed dose rate (quantity to represent the level of radioactivity) ( $R=0.604)$ whereas better positive correlation $(R=0.869)$ is observed between the absorbed dose rate and relative distribution of kaolinite. No correlation is observed between the relative distribution of other minerals and absorbed dose rate. Both absorbed dose rate and magnetic susceptibility are positively correlated with relative distribution of kaolinite, which suggested that their existence and abundances are controlled by common mechanism (i.e. abundance of clay minerals) in sediments. According to El-Arabi et al. [35] clay minerals are mainly composed of plate-like secondary aluminium silicates with small grain size and have a negative charged surface. Therefore, clay particles have the ability to absorb cations on their surface. Here, correlation analysis provides the same result. Moreover, this positive correlation shows that the radioactivity level of the sediments is controlled by magnetic susceptibility. Some investigations, like Ligero et al. [36], have shown the dependence of radionuclide concentrations on magnetic susceptibility. Here it is true.

\section{Conclusion}

The magnetic susceptibility of the Ponnaiyar river sediment varies due to the different inputs from different sources like catchment soils and rocks, atmospheric fallout like highway run-offs and other anthropogenic sources. This anthropogenic effect can be observed mainly in the last $100 \mathrm{~km}$ of the river. An elevated value of susceptibility is also observed at some locations of first $100 \mathrm{~km}$ due to the traffic activities. Elevated values of magnetic susceptibility in the river sediment together with a considerable enrichment proved to be a reliable indicator of anthropogenic stresses on the sediments. $\mathrm{SP} / \mathrm{SD}$ grains are contributed to the total susceptibility at $\mathrm{S}_{12}, \mathrm{~S}_{19}, \mathrm{~S}_{21}, S_{35}, \mathrm{~S}_{37}$, and $\mathrm{S}_{38}$. The multidomain grains may contribute to the total magnetic susceptibility in other sites. The infrared analysis of the sediments indicates the presence of minerals such as quartz, microcline feldspar and kaolinite as major minerals, and others are accessory. The calculated extinction coefficient values show that the amount of quartz is greater than microcline feldspar and very much greater than kaolinite in all the sites. Correlation analysis shows that the level of natural radioactivity and magnetic susceptibility of the present sediments mainly depends upon the amount of clay minerals.

The average activity concentrations of Ponnaiyar river sediment are within the world and Indian average values although some extreme values have been determined. According to Radiation Protection 112 (EC, 1999) and $U N S C E A R, 2000$ report, all calculated radiation hazard indices are lower than recommended level. Therefore, the sediments of Ponnaiyar river does not pose any significant radiological threat to the population when it is used as a building construction material.

\section{References}

[1] M. Knab, V. Hoffmann, E. Petrovsky, A. Kapicka, N. Jordanova, E. Appel, Environ. Geol. 49, 527 (2006).

[2] J.N. Pattan, G. Parthban, V.K. Banakar, A. Tomer, M. Kulkarani, J. Earth Syst. Sci. 117, 113 (2008).

[3] T. Yang, Q. Liu, L. Chan, Z. Liu, Environ. Geol. 52, 1639 (2007).

[4] M. Faheem, S.A. Mujahid, Matiullah, Radiat. Meas. 43, 1443 (2008).

[5] R.G. Sonkawade, K. Kant, S. Muralithar, R. Kumar, Atmos. Environ. 42, 2254 (2008).

[6] UNSCEAR, 2000. United Nations Scientific Committee on the Effect of Atomic Radiation. Report to the general assembly. Annex B: exposures from natural radiation sources.

[7] H. Taskin, M. Karavus, P. Ay, A. Topuzoglu, S. Hindiroglu, G. Karahan, J. Environ. Radioact. 100, 49 (2009).

[8] M. Krmar, J. Slivka, E. Varga, I. Bikit, M. Veskovic, J. Geochem. Expl. 100, 20 (2009).

[9] A. El-Gamal, S. Nasr, El-Taher, Radiat. Meas. 42 , 457 (2007).

[10] R.H. Dott, R.L. Batten, Evolution of the Earth, Mc Graw Hill, New Delhi 1976.

[11] V. Ramasamy, P. Rajkumar, V. Ponnusamy, Bull. Pure Appl. Sci. 25, 49 (2006a).

[12] M.A.E. Chaparro, J.C Bidegain, A.M. Sinito, C.S.G. Gogorza, S. Jurado, Stud. Geophys. Geod. 47, 121 (2003).

[13] M.A.E. Chaparro, J.C. Bidegain, A.M. Sinito, S. Jurado, C.S.G. Gogorza, Stud. Geophys. Geod. 48, 615 (2004).

[14] F. Desenfant, E. Petrovsky, P. Rochette, Water Air Soil Poll. 152, 297 (2004).

[15] F. Wehland, C. Panaiotu, E. Appel, V. Hoffmann, D. Jordanova, N. Jordanova, I. Denut, Phys. Chem. Earth 27, 1371 (2002). 
[16] B.A. Powell, L.D. Hughes, M.A. Soreefan, D. Falta, M. Wall, T.A. Devol, J. Environ. Radioact. 94, 121 (2007).

[17] V. Ramasamy, S. Murugesan, S. Mullainathan, Ekologia 2, 83 (2004).

[18] V. Ramasamy, S. Murugesan, S. Mullainathan, Indian Miner. 40, 9 (2006b).

[19] V. Ramasamy, S. Murugesan, S. Mullainathan, Indian Miner. 39, 91 (2005).

[20] V. Ramasamy, P. Rajkumar, V. Ponnusamy, Indian J. Phys. 83, 1295 (2009)

[21] X.S. Wang, Y. Qin, Environ. Geol. 49, 10 (2005).

[22] B.A. Maher, Geophys. J. 94, 83 (1988).

[23] Y. Narayana, K.M. Rajasekara, K. Siddappa, J. Environ. Radioact. 95, 98 (2007).

[24] I. Bikit, J. Slivka, M. Veskovic, E. Varga, N. Zikic-Todorovic, D. Mrda, S. Forkapic, Radiat. Meas. 41 477 (2006).

[25] B. Descamps, L. Foulquier, Radiat. Prot. Dosim. 24, 143 (1998).

[26] M.I. Chowdhury, M.N. Alam, S.K.S. Hazari, Appl. Radiat. Isot. 51, 747 (1999).

[27] J. Singh, H. Singh, S. Singh, B.S. Bajwa, R.G. Sonkawade, J. Environ. Radioact. 100, 94 (2009).
[28] Y. Orgun, N. Altinsoy, S.Y. Sahin, Y. Gungor, A.H. Gultekin, G. Karaham, Z. Karaak, Appl. Radiat. Isot. 65, 739 (2007).

[29] I.F. Al-Hamarneh, M.I. Awadallah, Radiat. Meas. 44, 102 (2009).

[30] J. Beretka, P.J. Mathew, Health Phys. 48, 87 (1985).

[31] EC1999, 1999. European Commission. Radiation Protection Unit, Radiological Protection Principles Concerning the Natural Radioactivity of Building Materials. Radiation Production. 112.

[32] M. Tzortzis, H. Tsertos, J. Environ. Radioact. 70, 223 (2003).

[33] D. Krstic, D. Nikezic, N. Stevanovic, D. Vucic, Radiat. Meas. 42, 1731 (2007).

[34] J.D. Russell, in: Infrared Methods - A Handbook of Determinative Methods in Clay Mineralogy, Ed. M.J. Wilson, Blackie and Son Ltd., New York 1987, p. 133.

[35] A.M. El-Arabi Adel, G.E. Abbady, A.S. Hussein, Nucl. Sci. Technol. 17, 123 (2006).

[36] R.A. Ligero, I. Ramos-Lerate, M. Barrera, M. Casas-Ruiz, J. Environ. Radioact. 57, 7 (2001). 